\title{
Dossiê temático: “Comunicação, (des)ilusões e (des)afetos"
}

\section{Dossier temático: "Comunicación, (des) ilusiones y (des) afectos" \\ Thematic dossier: "Communication, (dis) illusions and (dis) affects"}

\author{
Maximiliano Martin Vicente \\ Universidade Estadual Paulista "Júlio de Mesquita Filho" (Brasil) \\ $\underline{\text { mm.vicente@unesp.br }}$ \\ Érika de Moraes \\ Universidade Estadual Paulista "Júlio de Mesquita Filho" (Brasil) \\ erika.moraes@unesp.br \\ Larissa Pelúcio \\ Universidade Estadual Paulista "Júlio de Mesquita Filho" (Brasil) \\ larissa.pelucio@unesp.br
}

Fecha de recepción: 25 de agosto de 2019

Fecha de recepción evaluador: 28 de agosto de 2019

Fecha de recepción corrección: 30 de agosto de 2019 
Este dossiê celebra a XX Jornada Multidisciplinar do Departamento de Ciências Humanas da FAAC Unesp, realizada em outubro de 2018, que propôs repensar a relação entre a comunicação e a ilusão, refletindo sobre antigas e possíveis novas (des)ilusões. Em seus vinte anos de realização, a Jornada vivenciou um tempo histórico que contempla ilusões diversas. São (des)ilusões históricas, sociais, linguísticas, econômicas, jurídicas, psíquicas. Ilusões, enfim. Des-ilusões. Um tempo contemporâneo ao desenvolvimento da chamada era digital, que quebrou fronteiras e, simultaneamente, criou outras, a exemplo das redes-bolhas sociais. Propôs, também, ponderar a questão dos afetos e desafetos em nossa sociedade, das opiniões contundentes, por vezes vazias, capazes de incitar a violência.

Este conjunto de textos, remissivo à temática da Jornada, propõe despertar uma reflexão acadêmica sobre esses "sentimentos" - ilusões, desilusões, afetos, desafetos e suas mais variadas formas de expressão - como compõem os discursos, as memórias, as imagens sociais. As contribuições dialogam com os diversos campos das ciências humanas ou sociais aplicadas, evocando o tema direta ou indiretamente. Convidamos o leitor a observarem os parênteses que compõem as palavras do tema. Se são (des)ilusões, não são necessariamente ilusões ou desilusões. Se são (des)afetos, não são necessariamente afetos ou desafetos. A proposta é pensar as nuances entre o pessimismo (que pode impactar a ação) e o otimismo (quando esperanças diversas foram desconstruídas, em especial nos últimos vinte anos).

O Texto: O sensível como agente da esfera pública: o uso da razão e emoção no debate online sobre a proposta de proibição do Funk aborda a consulta pública realizada para ver a possibilidade de criminalizar essa manifestação cultural como crime de saúde pública a criança, aos adolescentes e a família. Os resultados obtidos, levando em consideração os ambientes online, comprovam que se utilizam de razão e emoção nas construções argumentativas e no posicionamento sobre a tentativa de proibir essa expressividade cultural.

No artigo: Políticas públicas de comunicação na Constituição de 1988: avanços, retrocessos e desafios futuros os autores se debruçam na análise das políticas públicas de comunicação previstas na Carta de 1988 procurando avaliar criticamente tanto os avanços como os retrocessos. Concluem que a anomia do setor se configura um retrocesso e que a regulação das normas constitucionais é um desafio para o amadurecimento democrático da sociedade brasileira.

Já no trabalho: A inter-incompreensão polêmica e sua versão solipsista em práticas de leitura emergentes o autor aborda dois efeitos das tecnologias digitais de informação e comunicação: seu efeito em relação ás práticas de leitura e seu papel quanto a universalização do conhecimento gerado pelas universidades e estudos de pesquisa. $\mathrm{O}$ resultado obtido tenta aproximar o ecumenismo solipsista e a uniformização dos modos de dizer no que se refere à produção de pesquisa.

Em: (Des) Ilusão da notícia: análise da construção da ilusão e da desilusão pela mídia na cobertura sobre o caso da fosfoetanolamina sintética os autores desenvolvem 
por meio da análise de conteúdo e da hermenêutica em profundidade como as notícias divulgadas pelo G1 sobre a substancia fosfoetanolamina sintética geraram sentidos diferentes ao criar a ilusão de que poderia tanto trazer benefícios como prejuízos para a população. O texto conclui, após realizar uma análise detalhada das notícias que a informação divulgada contribuiu para a construção de uma desilusão das instâncias políticas, científicas e médicas, além da opinião pública.

Consumo, cultura e publicidade: os olimpianos na revista Vogue Brasil parte da ótica antropológica do consumo para demonstrar como as publicidades da revista impressa Vogue Brasil associam as marcas de luxo a imagens com celebridades. Assim, criam a ilusão entre os consumidores de que ao consumir, em função dos os imaginários criados pelas propagandas, eles entram no universo desses heróis chegando a se identificar com os personagens das propagandas.

O artigo: De Paris a Brasília: Intelectuais, ideias e ilusões no Le Monde Diplomatique aborda a história da edição brasileira desse jornal a partir de três pontos: as condições contextuais da instalação da publicação francesa no país latino-americano, a dinâmica das relações entre intelectuais e jornalistas. Tomando como referência as crises de 2008 e de 2013 o texto evidência como o jornal caiu na armadilha da ilusão de um certo desenvolvimento latino americano e ignorou a dimensão das crises gerando, dessa forma, mais desilusão entre seus leitores.

O texto: Uma virada conservadora: pânico moral, (des)ilusões e (des)afetos no Brasil dos anos 2010 se detém na análise detalhada de como as pautas denominadas progressistas de décadas anteriores forma subvertidas aos poucos, de tal forma que hoje se encontram acuadas pela ação do Estado conservador que se nega a tratar de temas relacionados com a diversidade e os direitos humanos. Concluem que atualmente, apesar desse embate os temas relacionados om a diversidade permeiam também, e talvez até mais intensamente, os meios de comunicação tradicionais e digitais, merecedores, portanto, de estudos mais detalhados sobre a questão da diversidade.

O estudo: Infância nada iludida: o que dizem as crianças sobre os comportamentos e riscos on-line abre espaço par se pensar sobre a relação das crianças com a mídia digital. Mostrando as opiniões e narrativas das crianças o texto comprova que essa criança mantém certa dependência, destacando positivamente as atividades que são realizadas por estarem conectadas. Por outro lado, a criticidade infantil demonstra que estão atentas aos riscos a que podem estar sujeitas em rede e que concordam com mecanismos de controle e vigilância. Como resultado aponta como esse público infantil mantem a ilusão de poder intervir mais ativamente na definição dos temas do cotidiano que encontram na rede.

Mulheres no jornalismo esportivo brasileiro: uma análise da atuação profissional sob o olhar do mercado de trabalho trata da presença feminina nos programas esportivos da televisão aberta e entender a forma como os e as profissionais inseridos nesse contexto avaliam a relação entre esporte e gênero. Tal avanço significativo, por ser um espaço reservado para os homens, pode criar a ilusão de que está 
se progredindo em discussão e tolerância em relação a um tema tabu o que não se comprova, como conclui o artigo. Ainda resquícios do patriarcado se fazem presentes no meio esportivo.

Cardápio múltiplo e variado. Realizamos um convite para que sejam saboreados desde a ótica que motivou a origem da XX Jornada Multidisciplinar: refletir academicamente sobre esses "sentimentos" - ilusões, desilusões, afetos, desafetos e suas mais variadas formas de expressão - como compõem os discursos, as memórias, as imagens sociais.

Nosso agradecimento à revista ComHumanitas que desde os primeiros contatos nos abriu as portas para que pudéssemos expor parte do material produzido durante a XX Jornada Multidisciplinar, material esse múltiplo e variado que perpassa por áreas diversas, mas que dialogam entre si. Ao final todos trabalhamos com a mesma finalidade: ter um mundo mais humano, capaz de aceitar e conviver com as alteridades, fato esse que parece estar tendo um forte ataque por aqueles que não aceitam a tolerância e a diversidade. Diante disso a multidisciplinariedade, como pode ser observado nos textos apresentados tem muito a dizer. 